\title{
Les Cydalises
}

Où sont nos amoureuses?

Elles sont au tombeau!

Elles sont plus heureuses

Dans un séjour plus beau.

Elles sont près des anges

Dans le fond du ciel bleu,

Et chantent les louanges,

De la mère de Dieu!

Ô blanche fiancée!

Ôjeune vierge en fleur!

Amante délaissée,

Que flétrit la douleur!...

L'Éternité profonde

Souriait dans vos yeux:

Flambeaux éteints du monde, Rallumez-vous aux cieux! 